\title{
A Proposed Strategic Balanced Scorecard Model: Strategic Control System and Organizational Performance in Malaysian Automotive Industry
}

\author{
Nurul Fadly Habidin ${ }^{1}$, Sha'ri Mohd Yusof ${ }^{2,}$ Baharudin Omar $^{3}$, Syed Ismail Syed \\ Mohamad $^{3}$, Sharul Effendy Janudin ${ }^{3}$ \\ ${ }^{I}$ (Department of Management and Leadership, Universiti Pendidikan Sultan Idris, Malaysia) \\ ${ }_{2}^{2}$ (Department of Manufacturing and Industrial Engineering, Universiti Teknologi Malaysia, Malaysia) \\ ${ }_{3}^{3}$ (Department of Accounting, Universiti Pendidikan Sultan Idris, Malaysia)
}

\begin{abstract}
In the globalization era, Malaysian automotive industry is facing greater challenges due to the general quest for high quality, the requirement and regulation of ASEAN Trade Area (AFTA) and the increasing competition between local car and foreign car manufactures. Therefore, to increase the competitiveness, firms apply many quality program and initiatives such as Balanced Scorecard (BSC). The BSC strategy helps managers to manage strategic plan, monitor and control the performance result, encourages effective communication and discussion, provides reward based system, and feedback with quick action approach that aligns with organization goal. Managers need to focus on both financial and non-financial measures (customer, internal business process, and innovation and learning) to achieve organizational goals. The aim of this paper is to review the relationship between the strategic control system and organizational performance for Malaysian Automotive industry.
\end{abstract}

Keywords - Strategic control systems, organizational performance, balanced scorecard, automotive.

\section{INTRODUCTION}

The automotive industry is one of the most important and strategic industries in Malaysian manufacturing sector (Zadry, 2005). Nonetheless, after more than 27 years Malaysian automotive has been established, the performance of national car maker, supply parts by local suppliers still receive criticism, complaints, and various suggested approach to improve their product quality, operation management, and customer satisfaction. As a result, in order to improve the quality of automotive industries, Malaysian government has supported various quality initiatives, strategy and automotive policy such as vendor development program (PVD), zero defect, strategy partnership, and National Automotive Policy (NAP).

Balanced Scorecard (BSC) is considered as an important tool for aligning strategic goal, communication, planning, feedback and integrating financial and non financial measure from four important perspectives (financial, customer, internal business process, and innovation and learning) (Kaplan and Norton, 1992, 1996a,b) for better performance and in turn against competitive advantage. This paper will review on how balanced scorecard will assist to align between strategy and performance measure in order to improve organizational performance for Malaysian Automotive industry.

\section{LITERATURE REVIEW}

BSC is viewed in different perspectives by various authors such as strategic management tool (Rooriguez, 2008), strategic implementation tool (Andersen et al, 2004), or strategic management system (Kaplan and Norton, 1996a). However, the original BSC was created by Robert Kaplan and David Norton (1992) who argued that BSC was not only performance measurement, but also it aligned organizations with Strategic Control Systems (SCS) which directly translated an organization's strategies into action oriented plans.

\subsection{Strategic Control System}

Based on extensive review of the literature, this study discovers different elements of SCS that have been proposed by various researchers. Therefore, the SCS framework by Kaplan and Norton (1996a) is selected as the SCS framework of this study which includes clarifying and translating vision and strategy, communicating and linking, planning and target setting; and strategic feedback and learning. Furthermore, these four strategy elements of Balanced Scorecard (BSC) are strongly supported by previous study (Flamholtz et al., 1985; Goold and Quinn, 1993; Ittner and Larcher, 1997; Pinken and Dess, 1997; and Abas and Yaa'cob, 2006). Table 1 shows the proposed measurement item for strategic control system which are: clarifying and translating the vision and strategy, communication and linking, planning and target setting, and strategic feedback and learning as presented graphically in Figure 1. 
Table 1: Strategic control Systems construct and their measurement item

\begin{tabular}{|l|l|c|}
\hline \multicolumn{1}{|c|}{$\begin{array}{c}\text { Strategy control } \\
\text { systems }\end{array}$} & \multicolumn{1}{c|}{ Items } & References \\
\hline $\begin{array}{l}\text { Clarifying and } \\
\text { translating the vision } \\
\text { and strategy }\end{array}$ & Clarifying the vision; and Gaining consensus & \\
\cline { 1 - 2 } $\begin{array}{l}\text { Communication and } \\
\text { linking }\end{array}$ & $\begin{array}{l}\text { Communication and educating, Setting goals } \\
\text { and decomposing; and Linking rewards to } \\
\text { performance }\end{array}$ & $\begin{array}{c}\text { Korton,(1996a), } \\
\text { Ittner and } \\
\text { Larcker,1997, } \\
\text { and Ya'acob } \\
\text { (2008) }\end{array}$ \\
\cline { 1 - 2 } $\begin{array}{l}\text { Planning and target } \\
\text { setting }\end{array}$ & $\begin{array}{l}\text { Setting targets; Aligning strategic initiatives; } \\
\text { Allocating resources; and Establishing milestone }\end{array}$ & \\
\cline { 1 - 2 } $\begin{array}{l}\text { Strategic feedback } \\
\text { and learning }\end{array}$ & $\begin{array}{l}\text { Articulating the shared vision; Supplying } \\
\text { strategic feedback; and Facilitating strategy } \\
\text { review }\end{array}$ & \\
\hline
\end{tabular}

\subsubsection{Clarifying and translating strategy}

Organizations requires strategic system to align organization members to understand organization's vision and quality practice and improvement about strategy. In addition, organization member involvement, team work, involvement, collaboration, aligning between operation activities and management, and understanding the organization vision and goal are important factor in order to make strategy more effective. Thus, organization must explain strategy in clear and simple statement to make organization members understand the organization vision and strategy. To achieve organization strategy, top management should translate their vision so that it is easily understood by all level of organization members and ultimately put them into action (Irala, 2007).

\subsubsection{Communication and linking}

By communicating and linking strategy throughout the organization, it should practice the top bottom alignment, employee empowerment and employee reward to achieve strategy objectives and performance (Kaplan and Norton 1996a). As commonly reported in the quality and performance literatures, organizational member should be rewarded based on their performance (Goold and Quinn, 1990). This includes praise, promotions, and financial incentives (Kaplan and Norton, 2006). After achieving a clear understanding among the organization members on the organizational strategy and goal, the reward system of SCS needs to be implemented in order to attain organizational strategic objectives (Kaplan and Norton, 1996a). Additionally, this reward system programme should encourage commitment and motivation for employee to enhance their contribution to achieve strategy.

\subsubsection{Planning and target setting}

Another important element of SCS which is planning and target setting, involves the strategic planning process, strategic objective, strategy formulation, and development of action plan needed for achievement of organizational strategy (Flamholtz et al., 1985; Govindarajan and Gupta, 1985; Goold \& Quinn, 1993; Ittner and Larker,1995; Kaplan and Norton (1996b). According to Kaplan and Norton (1996b; 2006) the important target setting to organization is to assist and guide the smooth resources allocation and measure short term and long term financial and non financial performance. They also argue that management system needs to align planning and target setting to the organization strategy in order to achieve high business result.

\subsubsection{Strategic feedback and learning}

In the globalization and high competitive environment, feedback and learning from multiple perspectives are a timely aid in implementation of organization strategy (Kaplan and Norton, 1996). Strategic feedback and learning are important to identifying the strategic information regarding market and performance review, sharing vision and knowledge, and feedback for helping the organization to build and create long-term growth and improvement

\subsection{Organizational Performance}

Performance measurement is common in any firm, be it for measuring on financial aspect, nonfinancial aspect, or both financial and non-financial measurement. Based on that, Kaplan and Norton (1992) proposed multiple performance measure in balanced scorecard approach. These comprehensive measures of performance are based on four perspectives: financial, customer, business process/operation, and innovation/learning growth. Kanji (2002), suggested four key areas for measuring organizational performance, namely: maximize stakeholder value, achieve process excellence, improve organizational learning and delight 
the customer. These four key areas are also consistent with the four perspective of Balanced Scorecard as documented by Kaplan and Norton (1996a).

According Ittner and Larcker (1998) managers need to focus on both financial and non-financial measures to achieve organizational goals. The balanced comes from tracking not only financial performance measure such as operating income, sales growth and sales revenue, but non-financial ones as well. This is because non-financial measures are likely to facilitate organizational decisions and actions that support strategies based on the stakeholders need (Hoque and James, 2000). It has also been suggested (Kaplan and Norton, 1996a, 2001) that non financial performance measure helps managers to assess changes in the business environments, determine and evaluate progress towards the firm's goal, and affirm achievement of business performance.

Othman (2007) explored the adaptation of BSC in Malaysian organizations. From his finding, the reason for BSC adaptation is because it is a part of a process to improve performance, implement a major change in strategy, help manage a corporate turnaround process, to rationalize operation, integrate the operation of the organization, overcome past weaknesses in strategy implementation process, and ensure continuity of existing techniques.

\subsubsection{Financial}

On managing and improving business process, customer and employee satisfaction, the financial perspective should improve accordingly (Bhasin, 2008). The importance of financial performance is to measure whether organization strategy and implementation results the better bottom-line improvement, and good return to shareholders (Kaplan and Norton 1992, 1996, 2008; Irala, 2007; Jusoh et al., 2008).

Furthermore, improved sales revenue, sales growth, net profit and gross profit among financial measure are preferred by Malaysian manufacturing firm (Kassim et al., (1989). Financial performance in terms of profitability such as operating income, return on investment and economic value-added (EVA) (Kaplan and Norton 1992, 1996, 2008; Jusoh et al., 2008) and improved competition position, have been proven to increase market share, increase revenue, reduce expense, and improve financial results (Zakuan, 2009) which in turn has positive effect on measure of organizational performance. Given the evidence with supported arguments, the author believes that financial performance is one of the important measures for organizational performance.

\subsubsection{Customer}

The customer perspective on the performance will help an organization to be concern about quality of product and service, cost of their products, customer service and satisfaction, effectiveness of its delivery, and then align its internal business process well with customers in order to improve financial result (Kaplan and Norton, 1992, 2008; Jusoh et al., 2008). This perspective encompasses measures such as customer satisfaction, retention, response time, loyalty, market share, and on time delivery. (Kaplan and Norton, 2008; Jusoh et al., 2008; Eker and Pala, 2008).

Therefore, the information and analysis data gathered from understanding of customers' need based on specification and requirement will assist an organization to produce high quality product and service. This is because, customer's evaluation has a direct impact on organization performance (Johnson and Gustafsson, 2000). For example, information given for customer retention and loyalty gained through systematic service and follow-up investigations, including a form of exit interview with defectors (Zakuan, 2009). Other study by Kue et al., (2001) suggests an effort to improve customer satisfaction and practicing customer need analysis will improve productivity, sales growth, increase the company earning.

In summary, the author believes organizational performance can be measured by customer perspective which consists of seven elements namely increase market share, increase customer satisfaction, improve customer loyalty, improve customer presentation rate, reduce the number customer complaints, reduce the number of warranty claims, reduce the number of shipment returned due to poor quality, and reduce the number of overdue deliveries.

\subsubsection{Internal Business Process}

In order to develop internal business process measurement, top management should identify the operation management processes that give beneficial effects to organization strategy. This can be done through customer satisfaction, financial returns to shareholders, and increase of the employee skill level and satisfaction (Kaplan and Norton, 2004; Irala, 2007). Basically, operations management processes activities in manufacturing organization involving acquire raw materials from suppliers, convert raw materials to finished goods, distribute finished goods to customers, and manage risk (Kaplan and Norton, 2004). The key performance measures under this perspective may include such as manufacturing efficiency, quality, defect rate, and cycle time for continually improving the internal process (Kaplan and Norton, 1992, 1996, Jusoh et al., 2008). 


\subsubsection{Innovation and Learning Growth}

Learning and growth perspective can determine organization future in which it develops employee skill and satisfaction, improvement in technology system and procedure, and innovation of new market development (Kaplan and Norton, 1992, 1996; Jusoh et al., 2008; Eker and Pala, 2008). In short, innovation and learning growth accomplish two vital components focusing on how organization innovate and learn following these an organization strategy's which are: (1) the development of new product, new pattern, quality of leadership, new market, and new technology, (2) the improvement level of employee skill, health and safety, absenteeism, and satisfaction. Thus, innovation and learning growth measure is important to achieve long term-value creation process, competing for global demand, enhancement external product markets (Irala, 2007; Jusoh et al., 2008; Kaplan and Norton, 2008). This is also supported by (Kaplan and Norton, 1992; Eker and Pala, 2008) who opinionate that successful companies that innovate and learn growth in continually activity will improve value for customer, improve operation process, and increase return to shareholder.

For instance, the use of information technology in developing performance measure will assist an organization to focus on the causal relationship and linkages for each performance measure within organization and make it as more strategic performance evaluation (Kaplan and Norton, 2006; Neely et al., 2005). Other study by (Jun et al., 2006, Zakuan, 2009) finds that employee satisfaction has positive influence on organizational performance. In short, the combination of improved innovation, and learning growth of product, human, technology and market are essentials to support the organization strategy.

\section{PROPOSED FRAMEWORK MODEL: THE RELATIONSHIP BETWEEN SCS AND ORGANIZATIONAL PERFORMANCE}

SCS is a structural system that authorizes and help managers to manage strategic plan, monitor and control the performance result, encourages effective communication and discussion, provides reward based system, and feedback with quick action approach that aligns with organizational goal. SCS will have effect on the organizational performance in industry like automotive in this decade (Goold and Quinn, 1990; Kaplan and Norton, 1992; and Speckbacher et al., 2003), namely in:

- $\quad$ Monitoring the implementation of long-term strategy

- Coordinating and aligning between planning, communication, and organization goal

- Improving strategic planning such as control and feedback

- Improving alignment of strategic objectives with actions

- Focusing resources on strategy

- Developing a consistent system of objectives in the organization

- Improving understanding of cause-and-effect relationship in the organization

As mentioned, SCS and organizational performance from Kaplan and Norton (1992, 1996a, b) is chosen. Based on literature support and gap of this study, this study explores on how SCS approach and performance measurement of Malaysian automotive industry Thus, organizational performance is developed based on review of empirical study on quality initiatives performance measure.

This BSC provides a useful guidance for manufacturing, especially in automotive industry to evaluate and measure the quality initiatives using the balanced scorecard way. The different lean performance metric is categorized under four perspectives, and this assists the industry to evaluate lean and six sigma performance in BSC way from the angle of financial and non financial measurement perspectives (financial, customer, internal business process, and innovation/ learning growth). These approaches have been adopted in previous study by (Jusoh et al., 2008; Bhagwat and Sharma, 2007; Bhasin, 2008). In the future agenda, the relationship between SCS and organizational performance can be arranged in proposed model as in Figure 1.

\section{RESEARCH HYPOTHESES}

SCS will have effect on the organizational performance such as monitoring the implementation of long-term strategy, coordinating and aligning between planning, communication, and organization goal, improving strategic planning such as control and feedback, improving alignment of strategic objectives with actions, focusing resources on strategy, developing a consistent system of objectives in the organization, and improving understanding of cause-and-effect relationship in the organization (Goold and Quinn, 1990; Kaplan and Norton, 1992; and Speckbacher et al., 2003). According to their empirical study, Fullerton and McWatters (2002) evaluate the relationship between the JIT practices, control system, and performance measurement and incentive system in US manufacturing firm. The result points out that the successful implementation of JIT requires a complementary decision making and control system. Specifically, firm must adapt their control system by empowering worker and linking compensation rewards to improve organizational performance. Therefore the relationship between SCS and organizational performance is formulated as follow. 
H1: There is a positive and direct significant relationship between strategy control system and organizational performance of Malaysian automotive industry

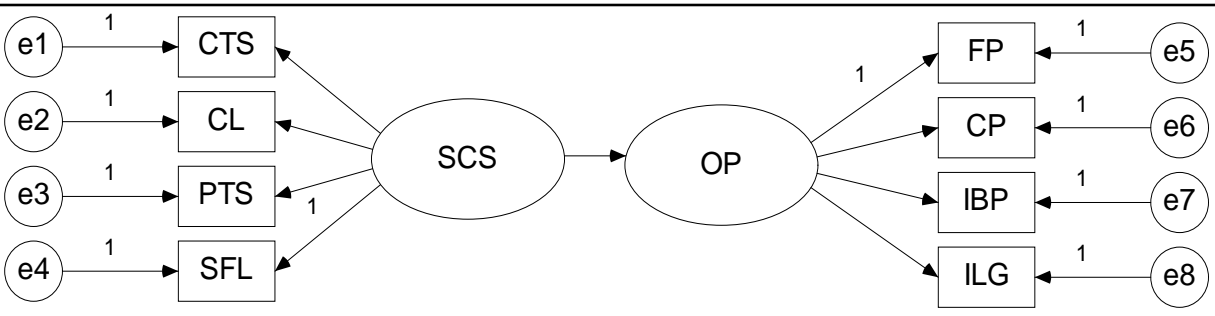

LATENTVARIABLE:SCS=Strategic Control System, OP = Organizational Performance

OBSERVED VARIABLE: Clarifying and translating the strategy (CTS), Communicating and linking (CL), Planning and target setting (PTS), and Strategic feedback and learning (SFL), Financial (FP), customer (CP), internal business process (IBP), and innovation and learning growth (ILG)

\section{Figure 1:}

Proposed structural relationship model between SCS and organizational performance

\section{CONCLUSION}

SCS and organization performance measure are become most importance strategy and it involves local car manufacturers and automotive suppliers in their effort to become more effective and competitive in their pursuit to enhancing the organization's ability to improve quality, business operation, customer and employee satisfaction and business performance. In addition, strategy and performance tools provide guideline and references to automotive industry especially to automotive suppliers.

\section{Acknowledgements}

The researchers would like to acknowledge the Ministry of Higher Education (MOHE) for the financial funding of this research thought Fundamental Research Grant Scheme (FRGS) and Research Management Centre (RMC), UPSI for Research University Grant (RUG).

\section{REFERENCES}

[1] Zadry, H. R. The integration of total quality management (TQM) and theory of constraints (TOC) implementation in Malaysian automotive suppliers. Master Thesis, Faculty of Mechanical Engineering, University Technology Malaysia, Malaysia, 2005.

[2] Kaplan, R. S., and Norton, D. P. The balanced scorecard-measure that drive performance. Harvard Business Review, JanuaryFebruary, 1992, 71-79.

[3] Kaplan, R. S., and Norton, D. P. The balanced scorecard-translating strategy into action, (Boston: Harvard Business Scholl Press,1996a).

[4] Kaplan, R. S., and Norton, D. P. Using the balanced scorecard as a strategic management system. Harvard Business Review, January-February, 71 (1), 1992, 75-85.

[5] Rooriquez, A. B. A framework to align strategy, improvement performance, and customer satisfaction using an integration of six sigma and balanced scorecard. Dissertation of Doctor Philosophy, Department, of Industrial Engineering and Management System, College of Engineering and Computer Science, University of Central Florida, Orlando, Florida, 2008.

[6] Andersen, H. V., Lawrie, G. and Savic, N. Effective quality management through third generation balanced scorecard. International Journal of Productivity and Performance Management, 53 (7), 2004, 634-645.

[7] Flamholtz, E. G., Das, T. K., and Tsui, A. N. Toward an integrative framework oforganizational control. Accounting, Organizations and Society, 11 (1), 1985, 35-50.

[8] Goold, M. \& Quinn, J. J. Strategic control: Milestones for long-term performance. London: Pitman Publishing, 1993.

[9] Ittner, C. D. \& Larcker, D. F. Quality strategy, strategic control systems and organizational performance. Accounting, Organizations and Society, 22 (3/4), 1997, 295-314.

[10] Picken, J. C. \& Dess, G. G. Out of (strategic) control. Organizational Dynamics, 26 (1), 1997, 35-48.

[11] Abas, Z., and Yaacob, Z. Exploring the relationship between total quality management (TQM), strategic control systems (SCS) and organizational performance (OP) using SEM Framework. The Journal of American Academy of Business, Cambridge, 9 (2), 2006, 161-166.

[12] Irala, L. R. Performance measurement using balanced scorecard, 2007, [Website] URL: http://ssrn.com/abstract=980691, [Assessed on $18^{\text {th }}$ July 2008].

[13] Goold, M., and Quinn, J. J. The paradox of strategic controls. Strategic Management Journal, 11(1), 1990, 43-57.

[14] Kaplan, R. S., and Norton, D. P. Alignment: using the balanced scorecard to create corporate synergies. Boston: Harvard Business School Press, 2006.

[15] Govindarajan. V., Gupta, A. K. Linking control systems to business unit strategy: impact on performance. Accounting, Organization and Society, 10 (1), 1985, 51-66.

[16] Ittner, C. D., and Larcker, D. F. Total quality management and the choice of information and reward systems. Journal of Accounting Research, supplement, 1995, 1-34.

[17] Kanji, G. K. Measuring business excellence. Routledge Advances inManagement and Business Studies. London, Routledge, 2002.

[18] Ittner, C. D., and Larcker, D. F. Innovations in performance measurement: trends and research implications. Journal of Management Accounting Research, 10, 1998, 205-238. 
19] Hoque, Z, and James, W. Linking the balanced scorecard measures to size and market factors: impact on organizational performance. Journal of Management Accounting Research, 12, 2000, 1-17.

[20] Kaplan, R. S., and Norton, D. P. The strategy-focused organization: how balanced scorecard companies thrive in the new business environment. Boston: Harvard Business School Press, 2001.

[21] Othman, R. Effects and effectiveness of the balanced scorecard: Malaysian evidence. Malaysian Management Review, 42 (1), 2007, 1-15.

[22] Bhasin, S. Lean and performance measurement. Journal of Manufacturing Technology Management, 19 (5), 2008, 670-684.

[23] Kaplan, R. S., and Norton, D. P. The execution premium: linking strategy to operations for competitive advantage. Boston: Harvard Business School Publishing Corporation, 2008.

[24] Jusoh, R., Ibrahim, D. N., and Zainuddin, Y. The performance consequence of multiple performance usage: evidence from the Malaysian manufacturers. International Journal of Productivity and Performance Management, 57 (2), 2008, 119-136.

[25] Kasim, A., Aziah, N., Minai, Badriyah., and Chun, L. S. Performance Measures in Malaysia-The State of the Art. Malaysian Management Review, 24, 1989, 3-9.

[26] Zakuan, N. M. Structural analysis of total quality Management, ISO/TS 16949and organizational performance in Malaysian and Thailand automotive industry. Phd Thesis, Faculty of Mechanical Engineering, University Technology Malaysia, Malaysia, 2009.

[27] Eker, M., and Pala, F. The effect of competition, just in time and total quality management on the use of multiple performance measures: an empirical study. Journal of Economic and Social Research, 10 (1), 2008, 35-72.

[28] Johnson, M. D., Gustafsson, A. Improving customer satisfaction, loyalty and profit: an integrated measurement and management system. San Francisco, CA: Jossey-Bass, 2000.

[29] Kuei, C., and Madu, C. N. Identifying critical success factors for supply chain quality management, Asia Pacific Management Review, 6(4), 2001, 409-423.

[30] Kaplan, R. S., and Norton, D. P. Strategy maps: converting intangible assets into tangible outcomes. Boston: Harvard Business School Press, 2004

[31] Neely, A. The evolution of performance measurement research: developments in the last decade and a research agenda for the next. International Journal of Operations and Production Management, 25(12), 2005, 1264-1277.

[32] Jun, M., Cai, S., and Shin, H. TQM practice in maquiladora: Antecedents of employee satisfaction and loyalty. Journal of Operation Management, 24, 2006, 791-812.

[33] Speckbacher, G., Bischof, J., and Pfeiffer, T. A descriptive analysis on the implementation of Balanced Scorecard in Germanspeaking countries. Management Accounting Review, 14 (4), 2003, 361-387.

[34] Bhagwat, R., and Sharma, M. K. Performance measurement of supply chain management: a balanced scorecard approach. Computer and Industrial Engineering, 53, 2007, 43-62.

[35] Fullerton, R. R., McWatters, C. S. The role of performance measures and incentive systems in relation to the degree of JIT implementation. Accounting, Organizations and Society, 27, 2002, 711-735. 